$$
\angle A-S U B=95-125
$$

\title{
1994 Annual Report of the Library Services Alliance of New Mexico
}

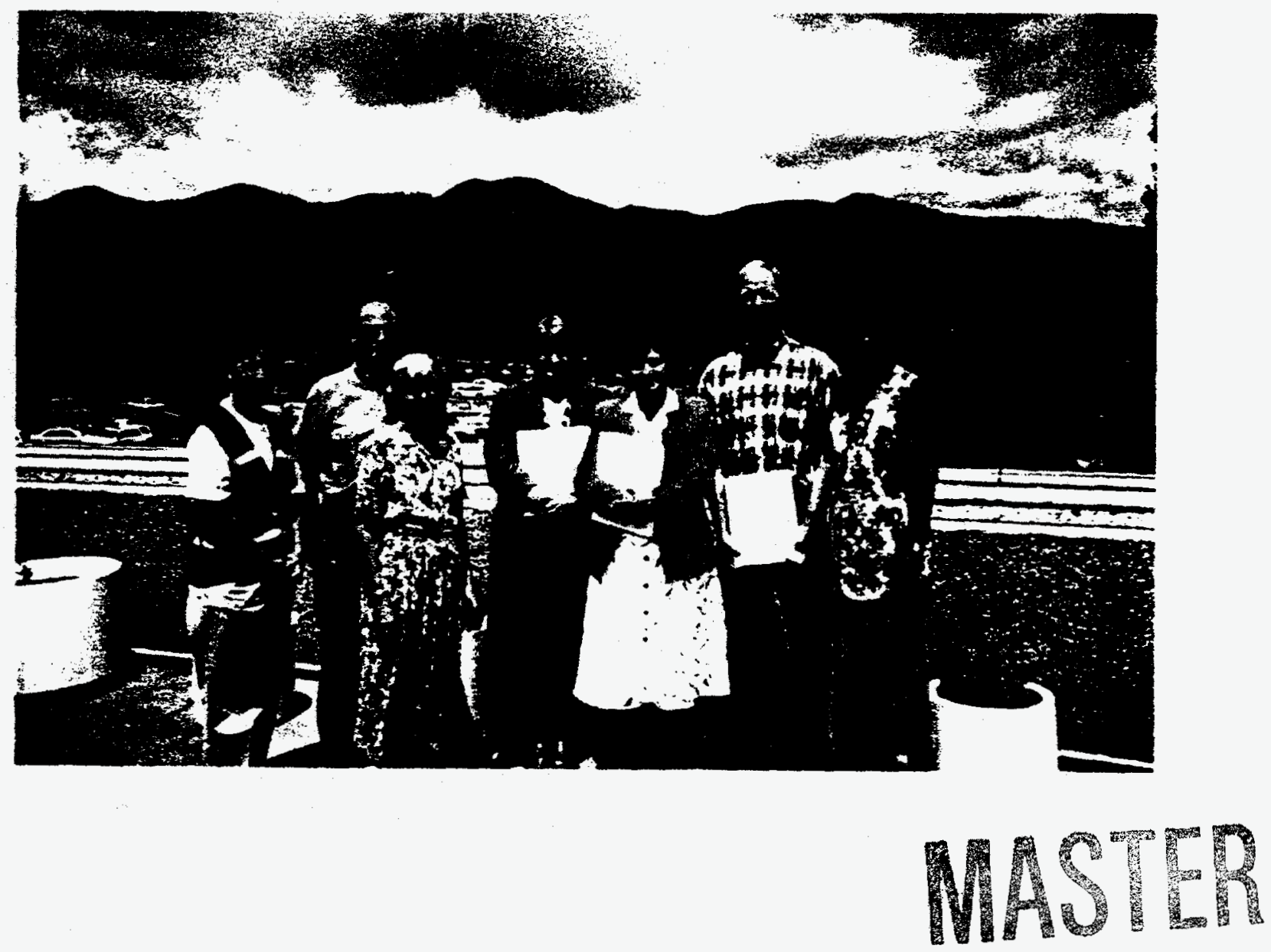




\title{
Contents
}

\section{Letter from the Chair, Directors Group}

\author{
Summary Report for 1994
}

\author{
Strategic Plan
}

\section{Sample Pages From the Alliance Gopher}

\section{American Library Association Poster Session Presentation}

\section{DISCLAIMER}

This report was prepared as an account of work sponsored by an agency of the United States Government. Neither the United States Government nor any agency thereof, nor any of their employees, makes any warranty, express or implied, or assumes any legal liability or responsibility for the accuracy, completeness, or usefulness of any information, apparatus, product, or process disclosed, or represents that its use would not infringe privately owned rights. Reference herein to any specific commercial product, process, or service by trade name, trademark, manufacturer, or otherwise does not necessarily constitute or imply its endorsement, recommendation, or favoring by the United States Government or any agency thereof. The views and opinions of authors expressed herein do not necessarily state or reflect those of the United States Government or any agency thereof. 


\section{DISCLAIMER}

Portions of this document may be illegible in electronic image products. Images are produced from the best available original document. 
On behalf of the Directors Group of the Library Services Alliance of New Mexico, I am pleased to submit the 1994 Annual Report.

The Library Services Alliance is a unique multi-type library consortium committed to resource sharing. As a voluntary association of university and governmental laboratory libraries supporting scientific research, the Alliance has become a leader in New Mexico in using cooperative ventures to cost-effectively expand resources supporting our scientific and technical communities.

During 1994, we continued to expand on our strategic planning foundation to enhance access to research information for our scientific and technical communities. Significant progress was made in facilitating easy access to the on-line catalogs of member libraries via connections through the Internet. Access to Alliance resources is now available via the World Wide Web and Gopher, as well as links to other databases and electronic information.

This report highlights the accomplishments of the Alliance during calendar year 1994.

Sincerely,

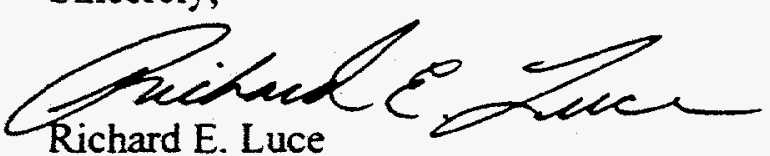

Chair, Directors Group 1994

Los Alamos National Laboratory
Directors Group:

Jeanne G. Howard

New Mexico State University

Harry P. Llull

University of New Mexico
Barbara Newton

Phillips National

Laboratory
Sally A. Landenberger

Sandia National Laboratories 


\section{Library Services Alliance of New Mexico}

\section{Summary Report for 1994}

The Library Services Alliance of New Mexico, a group of six academic and special libraries consisting of New Mexico State University, University of New Mexico, New Mexico Institute of Mining and Technology, Los Alamos National Laboratory, Phillips Laboratory and Sandia National Laboratories, was created in 1992. The mission of the Alliance is to enhance access to research information for the Alliance scientific and technical community through cooperative ventures. The Alliance continued in 1994 to promote the sharing of resources among its members.

\section{Strategic Plan}

The Alliance strategic plan, adopted in May, 1993, was updated and revised in 1994 as objectives under several goals were accomplished and new ones added. Five goals were identified for the strategic plan:

- Provide access to the electronic resources of Alliance member libraries.

- Deliver information products in a timely manner within the Alliance community.

- Maximize Alliance ownership of resources.

- Proide value-added information to researchers in the Alliance community.

- To fulfill the Alliance mission and vision, develop awareness of the Library Services Alliance throughout the state.

A copy of the plan is included in this report as Appendix A. The group agreed that the top objective for 1994 is to "Provide transparent Internet access to online public access catalogs (OPACs) of the member libraries".

\section{Highlights and Accomplishments}

Significant progress was made in achieving the top goal of facilitating easy access to the catalogs of the member libraries through Internet. Access is now available via the World Wide Web, using either a Gopher or Mosaic interface, and features not only access to the online catalogs of five of the institutions, but contains information about the staffs, other resources available, as well as images and links to other databases and electronic information. Using a hypertext browser, the user can click on the highlighted or colored portions of the screen, and another hyperdocument, further information, or an image will appear on the screen. Rather than needing to go to multiple sources to access catalogs and databases, all Alliance information is available in one place. Examples are shown in Appendix B of this report.

The Reference Working Group completed profiles for each of the institutions, which contain information about reference expertise, special collections, CD-ROMS and on-line services available at each institution, plus telephone numbers, hours and other useful information. As the year ends, the Alliance is in the process of making this information available via the Alliance Gopher. 


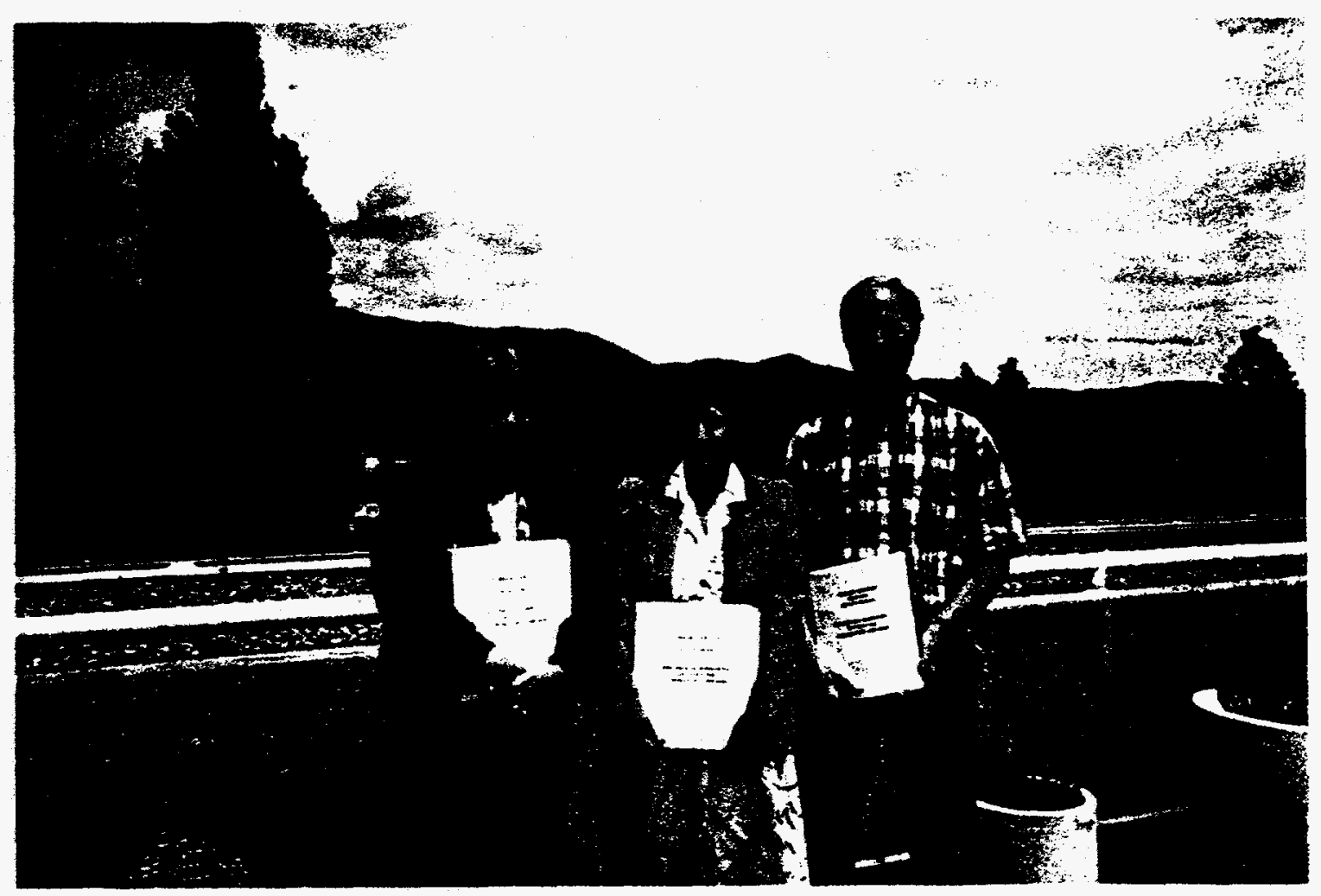

Laboratory Passport Agreement completed at LANL
Barbara Newton, Sally Landenberger, and Rick Luce

At the August 5 Directors meeting Barbara Newton, Phillips Laboratory, Sally Landenberger, Sandia National Laboratories, and Rick Luce, Los Alamos National Laboratory signed a reciprocal borrowing agreement on behalf of the three Laboratory libraries. This agreement extends borrowing privileges to staff from any of the three Labs. With a valid Library Passport card, Laboratory scientists may check out books from any of the participating institutions. The Alliance intends to integrate the Laboratory Passport program with the existing Passport program for academic institutions.

The group also reviewed its working bylaws and formally adopted the revised by-laws at the fall meeting.

The Collection Development Working Group met in November 1994 and agreed to work on a project to facilitate document delivery between Alliance libraries.

Jeanne Howard and Marilyn Von Seggern presented a poster session at the American Library Association annual conference in Miami on the topic "How to promote a library consortium". The session was well attended and a number of Alliance brochures were distributed. An abstract is included as Appendix C of this report.

The Alliance continued its interactions with the New Mexico State Library. In a May meeting, Harold Bogart from the State Library discussed new programs, including development of a statewide information network to connect all libraries in the state via the Internet. Rick Luce is a member of the Advisory Committee for this project. 


\section{Future Directions}

The Library Services Alliance of New Mexico will continue to work toward the goal of providing easy electronic access to member libraries. The Z39.50 interface has been implemented on the Geac Advance system at the Los Alamos National Laboratory and on the Sirsi system at Phillips Laboratory. This interface allows users at their home institution to search the catalogs and databases of member libraries using a software interface that is familiar to them. Work will continue with Geac to enhance this capability. The goal of the Alliance is to eventually provide this interface to all members' catalogs.

The Alliance agreed to work on a project to provide online access to Science Citation Index at each Alliance institution. The project, entitled Enhanced Access to Science Information (EASI), will maximize Alliance ownership of resources. The database, containing 10 years of science citations and abstracts, will reside on a machine at Los Alamos National Laboratory, with access available via the Internet. Licensing negotiations are underway with the vendor, and the group is working on a funding proposal.

Document imaging at the three national laboratories continues, and one of the strategic plan subgoals, to coordinate oprical imaging development efforts among Alliance members for the storage and access of specialized material, is ongoing. Representatives from the three Labs gave presentations about the imaging programs at the November Directors meeting.

In an era of rapid technology changes, it is important for Alliance members to be flexible and able to deliver services across multiple platforms via the Internet. The ability to provide library information through commonly used client tools, such as Mosaic, directly to the desktop is a key strategy for the Alliance. 


\title{
LIBRARY SERVICES ALLIANCE OF NEW MEXICO
}

Strategic Plan

\author{
Revised November 1994
}




\section{Library Services Alliance of New Mexico}

Mission: The mission of the Library Services Alliance of New Mexico is to enhance access to research information for the Alliance scientific and technical community through cooperative ventures.

Vision: The vision of the Library Services Alliance of New Mexico is to be a world-class information provider to our primary communities, while enhancing the scientific and technical research competitiveness for New Mexico.

Goals and Objectives: The Library Services Alliance of New Mexico desires to maximize the effectiveness of our individual resources to meet the following five goals:

Goal 1. Provide access to the electronic resources of Alliance member libraries.

- Provide transparent Internet access to on-line public access catalogs (OPACs) of member libraries.

-Actively move to support $Z 39.50$ as appropriate

-Provide access to the Sandia catalog by the end of March 1995

-Provide access to the Phillips catalog, resolving the password issue, by January 1995

-Technology Working Group

- Study and report on opportunities to pool resources for cost-effective sharing of electronic databases.

-Collection Development Working Group and Technology Working Group

- Develop Gopher and Mosaic as a vehicle to distribute information about Alliance resources

- Los Alamos will take a lead role in hosting and supporting Mosaic and Gopher resources 
Goal 2. Deliver information products in a timely manner within the Alliance community.

To fulfill this goal, the Alliance will

- Provide information delivery reciprocity for Alliance library users.

- Directors will review full text resources list provided by Steve Rollins -Directors Group will identify a strategy to accomplish this by December 1994

- Coordinate optical imaging development efforts among Alliance members for the storage and access of specialized material.

-Identify technical people at the three Labs and get them together to share information and put together a presentation by the fall Directors meeting Completed: November 1994

- Provide borrowing reciprocity for Alliance Library users.

-Test and evaluate the agreement among Laboratory library users for six months

-Review results and have a broader discussion at the spring 1995 meeting -Three academic libraries will review what the Labs have done as well as the academic libraries' existing Passport program by the spring 1995 meeting.

Goal 3. Maximize Alliance ownership of resources.

To fulfill this goal, the Alliance will

- Explore options for developing Alliance purchasing or licensing agreements to leverage our buying power.

- Identify access issues to medical and legal library resources at UNM -Explore Passport access issues 
Goal 4. Provide value-added information to researchers in the Alliance community.

To fulfill this goal, the Alliance will

- Develop an expert referral network of Alliance library staff.

- Update and publish library profiles by October 1.

-Reference Working Group

- Prepare and submit a proposal for grants to obtain resources to subsidize specific Alliance activities.

Goal 5. To fulfill the Alliance mission and vision, develop awareness of the Library Services Alliance throughout the state.

To fulfill this goal, the Alliance will

- Reach out to the professional library community by presenting a poster session at the New Mexico Library Association meeting to be held April, 1995 in Ruidoso.

-NMSU (Howard) and NMT (Reynolds) 


\section{Library Services Alliance of New Mexico}

The Library Services Alliance of New Mexico is a cooperative organization which promotes the sharing of resources among its members to enhance access to scientific and technical research information.

Founded in January 1992, the Alliance is made up of libraries at the three New Mexico research laboratories and three New Mexico universities that have the major science and technology collections in the state.

Los Alamos National Laboratory Research Library

New Mexico Institute of Mining and Technology Library

New Mexico State University Library

Phillips Laboratory Technical Library

Sandia National Laboratories Technical Library

University of New Mexico Libraries

\section{The goal of the Alliance is to meet the needs of researchers by:}

sharing electronic resources

working together to enhance the combined collections of the member libraries

providing fast interlibrary document delivery

sharing access to the expert knowledge of library staff

\section{Combined Collections}

The combined collections of the Alliance institution libraries compare in size to some of the major research libraries in the United States. The following collection statistics illustrate this strength.

Books \& Bound Periodicals........3,317,170

Government Documents \& Reports....1,925,582

Current Periodical subscriptions.....28,419

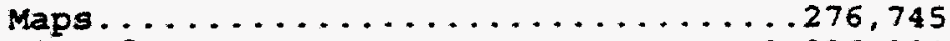

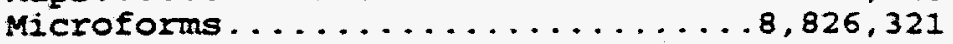

Alliance Libraries expect to expand use of various networks such as the Internet and Technet to enhance electronic access to the collections and services of the Alliance. Currently the three catalogs of the university libraries and the Los Alamos National Laboratory are available through these networks. For more up-to-date information on the status of electronic access to the libraries of the individual members of the Alliance, please contact the respective library.

\section{Hours}

Library hours at the Library Services Alliance institutions vary. Some collections in the laboratory libraries are classified. Call ahead before making a trip.

\section{Interlibrary Borrowing}

Interlibrary borrowing, lending, and document delivery among New Mexico Library Services Alliance institutions is provided upon request. Check with the Alliance library nearest you for details.

\section{PASSPORT Program}

PASSPORT is a reciprocal borrowing agreement for the libraries of Los Alamos National Laboratory, Sandia National Laboratory and Phillips Laboratory. Laboratory staff, with proper badge identification and a PASSPORT may:

Use the unclassified, unlimited research materials in the collections of participating Laboratory libraries on the premises of the owning library.

Borrow circulating books from the owning library. 
Los Alamos National Laboratory Research Library

Box 1663, MS P362

- Los Alamos, NM 87545

Phone: +1505.667 .5809$

Fax: +1 505.665.2948

Online Catalog: Seac ADVANCE

Home Page: Research Library

Gopher Server: Research Library

Home Page: LANL

Map: Route to Los Alamos

\section{Collection strengths}

physics

chemistry

engineering

mathematics

computer science

earth and environmental sciences

conference proceedings

LANL Technical Reports

collected writings

reference sets in physics and chemistry

early S.C.I. indexes (1945-)

A.E.C. period publications

\section{CD-ROM Titles}

ABI/Inform Business Periodicals

Aerospace Database

Biological Abstracts

Books in Print

CA Surveyor:

Cancer Chemical Research

Chromatrography

Magnetic Resonance

Organometallic Chemistry

CAS 12 th Collected Index

Code of Federal Regulations

Compendex Plus

Computer select

DROLS

Energy Database

Faxon Finder Database

Georef

IHS World wide Standards

INSPEC

Mathsci

Metadex Database

Meteorological \& Geoastrophysical Abstracts

NTIS

Nuclear Science Abstracts

Science Citation Index

Standard \& Poor's

Thomas Register

Ulrich's Periodicals

U.S. Code

Weissman Travel Reports 


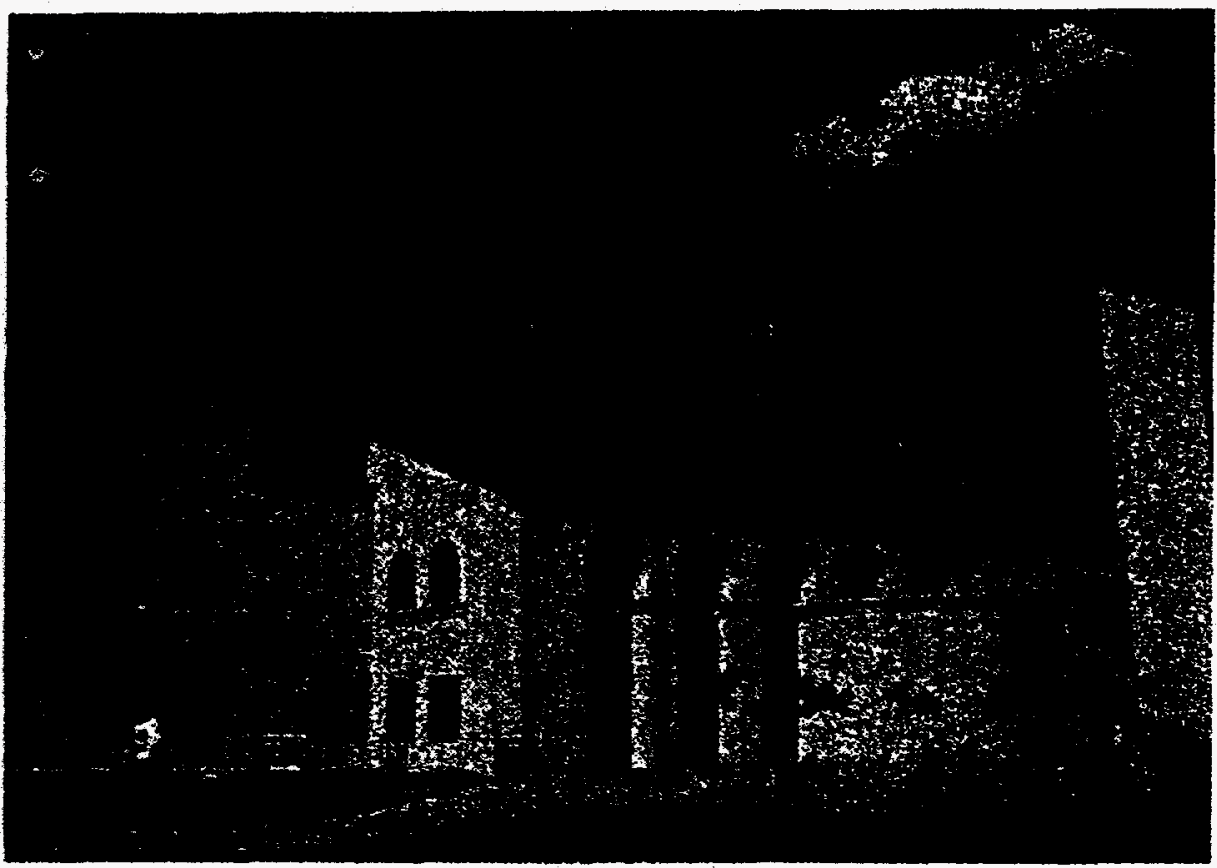

\section{New Mexico Institute of Mining and Technology Library}

Campus station

Socorro, NM 87801

Phone: +1505.835 .5891$

Fax: +1505.835 .5754$

Online Catalog: LIBROS

Home Page: New Mexico Tech Library

Home Page: New Mexico Tech

\section{Collection strengths}

Geosciences and geological engineering Mineral engineering

Materials and metallurgical engineering

Petroleum and natural gas engineering and secondary recovery of oil

U.S. Geological Survey and Bureau of Mines publications

\section{CD-ROM Titles}

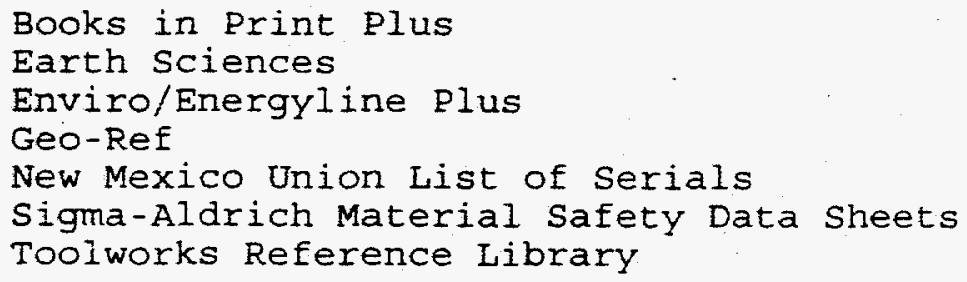




\section{New Mexico State University Library}

Branson Hall Library

Box 30006, Dept. 3475

Las Cruces, NM 88003-0006

Phone: +1505.646 .4129$

Fax: +1505.646 .7477$

Online Catalog: OLE

Home Page: New Mexice State University Iibrary

Home Page: New Mexice State

Gopher: NMSU Library Gopher

|collection strengths

agronomy and horticulture

animal and range sciences

arid lands

codes and standards

geology of North America

astronomy

entomology

computer science

molecular biology

psychology

biochemistry and genetics

chemical, civil, mechanical, electrical, electronic and computer engineering

CD-ROM Titles

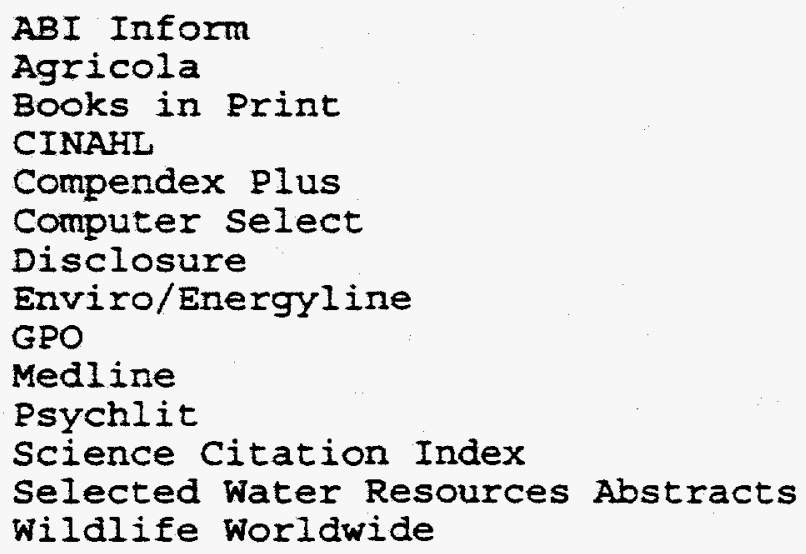

ABI Inform

Agricola

Books in Print

CINAHL

Compendex plus

Computer select

Disclosure

Enviro/Energyline

GPO

Medline

Psychlit

Science Citation Index

Selected water Resources Abstracts

Wildlife Worldwide

Other CD-ROMs related to social sciences, arts, education, and humanities are available in New Library.

Branson Hall Library houses the science, engineering, agriculture and business collections. 
Phillips Laboratory Technical Library

- 3550 Aberdeen Avenue SE

Kirtland AFB, NM 87117-5776

Phone: +1505.846 .4771$

Fax: +1 505.846.1194

Online Catalog: STILAS

Home Page: Phillips Iaboratery

Collection strengths

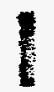

American Institute of Aeronautics and Astronautics (AIAA) meeting papers on microfiche $(38,000)$

SPIE proceedings collection $(1,300)$

al1 new DTIC documents received on fiche

over 250,000 NACA/NASA documents

CD-ROM Titles

Books in Print

Federal Register

Military Personnel Locator

New Mexico Union List of Serials 
Technical Library Information Research Dept.

Sandia National Laboratories

MS 0899

P. O. BOX 5800

Albuquerque, NM 87185-0899

1

Online Catalog: Dynix Marquis

Home Page: Technical Library

Home Page: SNL

(1)

Information Numbers

(

Circulation Desk 844-2738

Reference Desk 845-8287

Fax Number 844-9778

Document Delivery 845-8195

Hours $8: 00-4: 30 \mathrm{M}-\mathrm{F}$

Parking Visitor parking in front of main building

Access Restricted, special arrangements may need to be made

Reference Department Head and Phone Number Susan Stinchcomb 845-8493

E-Mail sstinch@somnet.sandia.gov

Reference staff

Professional - 8

clerical - 7

Library type (e.g., DOD, DOE, University) DOE

(Depository (e.g., NASA, patents, standards) None

Special Collectlons and Treasures Sandia reports

collection strengths

Reference Services (and costs)

Reference staff Members

Networks used

Automation

on-line retrieval systems

CD-ROM systems

EM Networks :

Internet

Updated: $2 / 21 / 95$ 


\section{Sandia National Laboratories Technical Library}

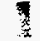

Detailed Information

Collection strengths

Materials Science (including Chemistry and Solid state Physics relating to

Materials Science),

Computer science (especially Parallel Computing, Electrical Engineering),

Reports (Nuclear Science and Technology, Nuclear Weapon Systems and Engineering)

The Technical Library supports research and development in: materials science, energy, nuclear weapons, advanced military technology, arms verification and control, environmental testing, applied mathematical sciences, and applied research in numerous scientific fields, including health care, transportation and electronics.

Return to previous page.

Reference Services

The Reference Department is a cost-recovering service center. How can we serve Alliance members? Information desk services are provided at no cost. Technical Information specialists can do brief consulting only, considered part of overhead.

Return to previous page.

\section{Reference Staff Members}

Our reference service is known officially as the Technical Library Information Research Department. We currently have 8 Technical Information Specialists. Of these. 3 are assigned to projects (Reference-related) and the other 5 are part of the (Reference) Service center. Subject specialties include assignments and also background knowledge. Our department also includes document delivery (includes ILL), circulation, ready reference, and reports reference. We serve all information needs for all Sandia employees, technical and administrative. There are several disbursed (departmental) libraries at Sandia serving specialty needs, such as the Education Outreach Resources Center.

Information Desks - Library Assistants General Reference -- Sharon Gorman -- 845-8287

Reports Reference -- Connie Souza -- 845-8187

They refer request to Technical Information Specialist if needed

Document Delivery - Service Center Co-ordinator -- Ken Cutshall -- 845-8426

Library Assistant - - Pat Chisholm - 845-8195

ILI -- Eloisa Maldonado -- 844-2897

Photocopy -- Debbie Luna - 844-5461

Technical Information Specialists - Service Center (Reference) Fax - 844-3143

Ken Cutshall - 845-8426 -- kjcutsh@somet .sandia.gov Chemistry, Market Research, Document Delivery, Internet

Julie Kesti -- 845-8044 -- jakesti@somnet.sandia.gov ES\&H; Health Sciences

David Mays 845-9429 emays@somnet.sandia.gov Physics, Market Research, Technology Transfer

Judy Neff 845-8386 joneff@somnet.sandia.gov ES\&H; , Health Sciences, Legislate

Glenda Sweatt 845-9351 gksweat@somnet.sandia.gov WIPP, Yucca Mountain, Hazmat Transportation, Radioactive Waste Management Technical Information Specialists - Projects

Ferne Allan - 845-8218 - fcallan@somnet.sandia.gov Alliance Reference Contact, Dynix Horizon, FOIA, OSTI, Materials Science

Mary Compton -- 845-9268 -- mlcompt@somnet.sandia.gov Alliance Collection Development contact, Collection Management Coordinator (Policies, Procedures, Selection), Internal Reports, Serials

Judy Geitgey -- 845-9460 -- jageitg@somnet.sandia.gov 
Return to previous page.

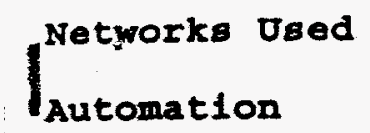

Bibliographic Utility

$\int_{\text {OCLC, RLIN }}^{\text {Bibliographic }}$

Library Catalog

| DOBIS -..... Dynix Horizon

Return to previous page.

fon-line Retrieval systems

Major

\begin{tabular}{|l} 
CLEO (OSTI) \\
Compuserve \\
Datastar \\
DIALOG \\
ITIS (OSTI) \\
Lexis/Nexis \\
STN \\
DOw Jones \\
DTIC \\
Legislate \\
NASA \\
NLM/Medlars \\
OCLC \\
ORBIT \\
PEriscope \\
GIDEP \\
RLIN \\
\\
APQC/IBC \\
Best NA \\
Electronic Tribune \\
APS/What's New \\
CINDAS \\
CISTI \\
DOE Orders \\
EPIC \\
Federal Bulletin board \\
FirstSearch \\
NNDC \\
NRC/PDR \\
UNM \\
Occasional Use
\end{tabular}

Return to previous page.

DD-ROM Systems

ABI/Inform Global, 1987-

Aerospace, 1989 -

AIDA, Artificial Intelligence Database of Abstracts, 1954-

Books in Print, current

Books out of Print, current

CASSIS/ASIST

CASSIS/BIB

CASSIS/CLASS

Computer select, 1 year

Dialog Bluesheets, current

Directory of Federal Lab \& Technology Resources DOE، 1974-

Ei - Compendex Plus, 1990- 
- -

Global Explorer, current

INSPEC, 1989 -

Map ' $n$ ' Go

Map Expert, current

McGraw-Hill Sci-Tech Reference Set, 1992

Microsoft Bookshelf, 1994

Microsoft Encarta, 1994

Monterey Institute nonproliferation databases, current

National Trade Data Bank (NTDB), current

NMULS, current

NTIS, 1980-

Nuclear Science Abstracts, 1948-1976

OSHA

PC Globe \& PC USA, current

Phonedisc, current

Science Citation Index, 1991-

SPE Masterdisc

Statistical Abstract, 1993

Ulrich's International Guide to Periodicals, current

Return to previous page. 
University of New Mexico

Albuquerque, NM 87131

Online Catalog: LIBROS

online Catalog: Medical Library

Fome Page: UNM

Information Numbers

Reference 277-4412

Circulation 277-4858

Fax 277-0702

E-Mail Reference csclrcf@unmb.unm.edu

Hours $\quad$ M-Th $\quad F \quad S \quad S$

Fal1, Spring

$\begin{array}{lllll}\text { Semesters } & 8: 00-10: 00 \mathrm{pm} & 8: 00-6: 00 & 10: 00-6: 00 & 12: 00-8: 00 \\ \text { Summer } & 9: 00-7: 00 & 9: 00-6: 00 & 1: 00-5: 00 & 1: 00-5: 00 \\ \text { Intersessions } & 9: 00-6: 00 & 9: 00-6: 00 & 1: 00-5: 00 & \text { closed }\end{array}$

Intersessions $9: 00-6: 00 \quad 9: 00-6: 00 \quad 1: 00-5: 00$ closed

Parking Not easy, a permit is required at all times, except weekends. Paid parking is available in Visitor's Parking in front of Popejoy Hall, and a commercial lot near University and Grand. There is also some metered parking in the lot nearest CSEL.

Access Anyone is welcome to come into and use anything in the library. There are numerous copy machines to use at 10c/copy, or the Copy Center can make copies for people, at 15c/copy. A community borrowers card may be purchased at Zimmerman Library. This allows people to check out up to 10 books at a time for two weeks. It is good for one year. of course, we may eventually have different arrangements for clients of the Alliance libraries.

Reference Department Head and Phone Number Donna Cromer 277-4753

E-Mail dcromerohal unm. edu

Reference staff

Professional - 8

clerical - 0

Student Assts - 0

Other - occassional volunteers from other parts of UNMGL, and other staff in CSEL

Iibrary type (e.g., DOD, DOz, Oniversity) University (ARL)

Depositery le.gen NASA, patentse standardsl

Special collections and Treasures

Reference Services (and costs)

Reference staff Members

Setworks used

Automation

On-line retrieval systems

CD-ROM systems

Updated: $3 / 20 / 95$ 


\section{Centennial Science and Engineering Library}

University of New Mexico

裙

Detailed Information

Depository

US GPO:UNMGL is a Regional GPO Depository. Most of the g overnment documents reside in Zimmerman Library, but some agencies in CSEL, such as:

Dept. of Commerce

patent and Trademark office

National Institute of Standards and Technology

NTIS (but only documents actually published by GPO)

Dept. of Defense Army Corps of Engineers

Dept. of Interior

Bureau of Mines and the US Geological Survey

NASA

Nuclear Regulatory Commission

and maps from various government agencies

Patents and Trademarks: CSEL is a Patent and Trademark Depository Library

DOE: CSEL receives DOE fiche

NASA: CSEL receives NASA fiche

Return to previous page.

Special Collections and Treasures

Map and Geographic Information center: MAGIC is a depository library for US government produced maps, such as topographic and coastal survey maps. It also collects extensively for New Mexico, the Southwest US, and Latin America. It is the largest map collection in the state. Air photos are significant resource.

Engineering and scientific society publications: we get all the journals and fonference proceedings of IEEE, ASME, and ASCE, as well as some from numerous other fengineering organizations. We also get all AIP Conference proceedings.

Ecology/biology: compared to all the other Alliance libraries (except NMSU) we have the most extensive collection in the life sciences.

Return to previous page.

Reference Services

We provide a full range of reference services, normally for all hours the library is open (although this may vary at times). This means staffing a reference desk for in-person patrons, telephone reference, and e-mail reference (although this is only (used VERY sporadically). A lot of what we do is help patrons determine if we have what they need/want, since it can sometimes be confusing to figure out the system. For things we don't have, we send patrons (university affiliated) to Interlibrary Loan, and for non-UNM, we offer Document Delivery Services. We spend a lot of time helping people with IIBROS and CD-ROM's. We will do on-line ready reference when the situation warrants it (but this varies by each librarian's comfort level with on-line (searching). We don't do very much on-line searching otherwise, because we have a 
vigorous ena-user craining program, using Dialog's Classmate Program (for students on'ly). Our faculty don't seem to require searches very often.

our primary clientele is UNM faculty, staff, and students. We also service anyone else who asks, though not always to the same degree. Our emphasis is on those in the library in person. We also try to be cognizant of other resources in the area in order to give good referrals

Return to previous page.

\section{Reference staff Members}

We have 4 faculty librarians and 4 library specialists. We each also have other responsibilities, including collection development and liaisons for one or more departments and/or responsibility for one or more operations/services in CSEL, among other duties. We assume the person with responsibility for a particular department is also the subject specialist for that area, plus an individual's background may provide specialties. Other staff in CSEL may spend some hours on the reference desk, and others also have collection development responsibilities (CD is described in full in other Alliance material). Questions may be referred to them by reference staff

(1)

Donna Cromer -- 277-4753-- dcromer@hal.unm.edu

Astronomy; Physics; Electrical Engineering; Computer Engineering; Technical

Reports

Coordinator of Reference Services

Diana Northrup - 277-5232-- dnorthup@hal.unm.edu

Biology; Chemistry

Co-Coordinator on on-line systems

Andrea Testi -- 277-4760-- atestighal.unm.edu

Biomedical; Mathematics; Statistics

Collection Development Coordinator for Science and Engineering

Dena Thomas -- 277-5327-- dthomas@hal.unm.edu

Civil Engineering; Environmental science; Patents and Trademarks;Government

Documents

Kash Heitkamp -- 277-5446-- heitkamp@hal.unm.edu

I

Geology

Co-Coordinator of on-line Searching; some Technical services

Dan Mahoney -- 277-3764-- dmahone@hal.unm.edu

Chemical Engineering; Nuclear Engineering

CSEL's computer expert, takes care of $\mathrm{Hal}$, and all the reference machines

Isusan Magee -- 277-5410-- smagee@hal.unm.edu

Coordinator of Bibliographic Instruction

Emily Terrell - 277-8522 - eterrell@hal.unm.edu

Mechanical Engineering; Reference

Assistant Coordinator of Reference Services

Return to previous page.

Networks Used

Automation 
OCLC

Library Catalog

- Innovative Interfaces, Inc. (LIBROS)-- (Internet access: library.unm.edu; login as library, no password needed)

Return to previous page.

on-line Retrleval Systems

OCLC

Firstsearch (we don't use EPIC in CSEL, though other people at UNMGL do)

Dialog

STN

Medline

CARL/UnCover (through LIBROS)

Wilsonline

DTIC

Expanded Academic Index (this is accessible through LIBROS, and is a periodicals index)

Return to previous page.

CD-ROM Systems

Wilsondiscs

Applied Science \& Technology Index (1983-)

Biological \& Agricultural Index (1983-)

General Science Index (1983-)

Silver Platter

Biological Abstracts (1990-)

Georef (1870's-)

NTIS $(1985-)$

USPTO

Patents Bibliographic (1969-)

Classification (al1)

Trademarks, registered and pending

WeatherDisc

PC/USA (US Sensus maps

We also have a large collection of CD's published by GPO, but do not use these very often, if at all. They are not loaded for patrons or staff to use, but can be on demand.

Return to previous page. 


\section{Science Citation Index}

This data base currently consists of 1.6 million citations. This database is going to grow to over 7 million citations in the near future.

For some examples of valid searches see examples.

Author

Title

Source

Institution

Reywords

Abstract, title

or keyworda

Document Type Language

Select years to search (Defaults to 1994/1995):

\begin{tabular}{|llllll}
1985 & 1987 & 1989 & 1991 & 1993 & 1995 \\
1986 & 1988 & 1990 & 1992 & 1994 & Al1 years
\end{tabular}

Dieplay type: Brief Medium Pull

Maximm number of citations to retrieve: 


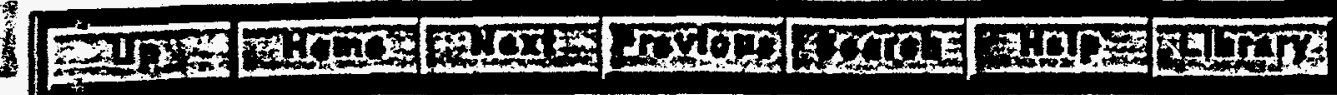

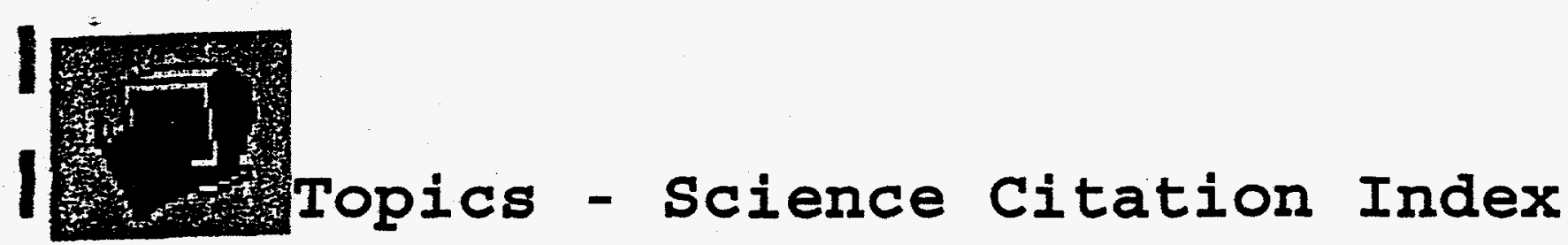

This document contains a list of topics that can be used to search the Science Citation Index Data Base. If you double-click on the topic name, the documents most relevant to the topic selected will retrieved.

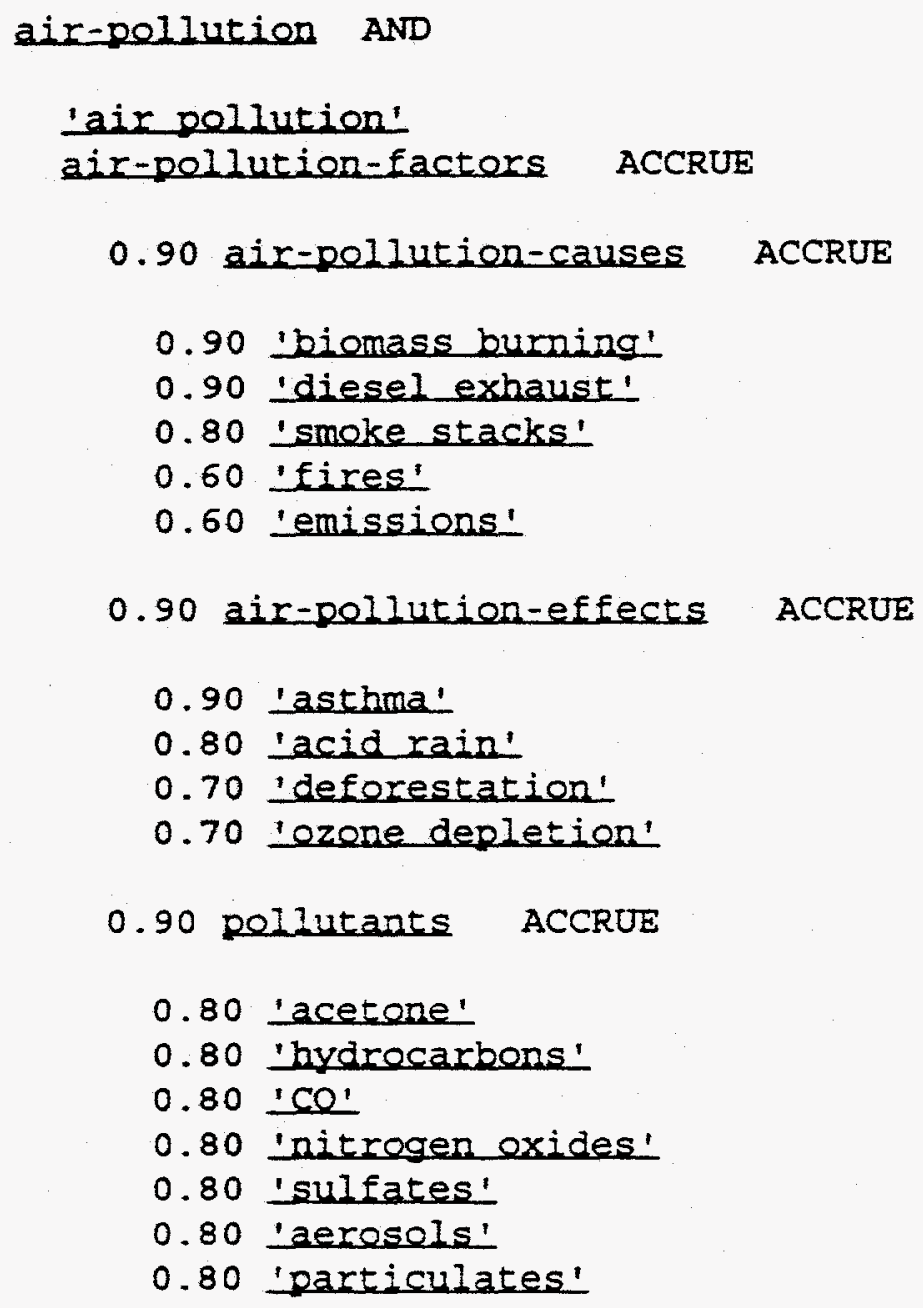




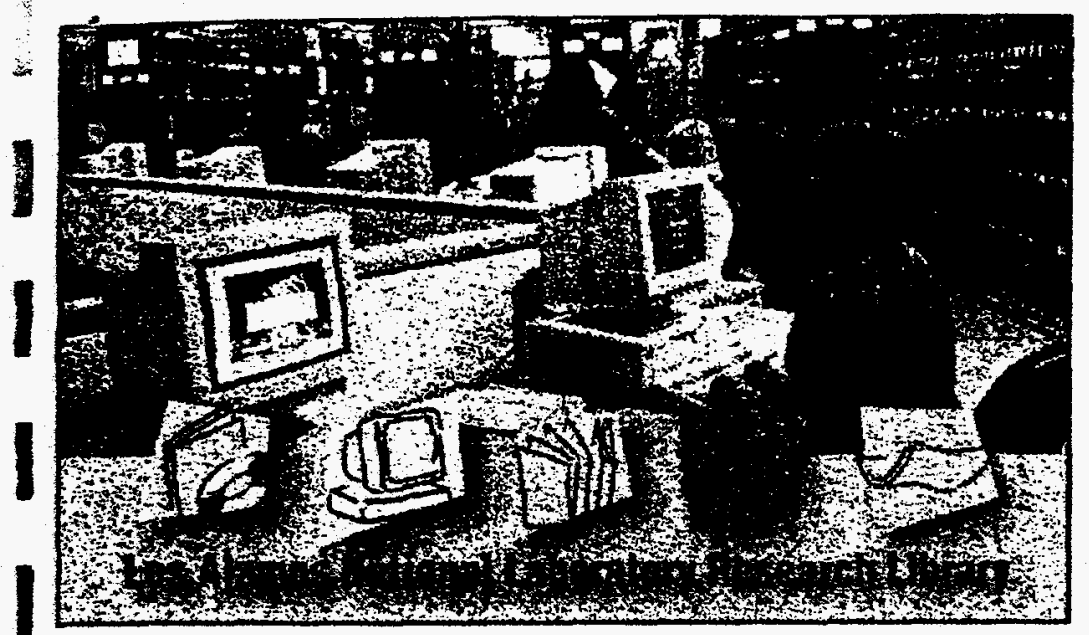

\section{Welcome to the Los Alamos National Laboratory Research Library}

The Los Alamos National Laboratory Research Library is home to a collection of books, journals, technical reports, and electronic databases that support the research efforts of the Los Alamos Narional Lahuration.

The Library is also the access point for electronic versions of Los Alamos Publications, part of the Library Without Walls project.

Los Alannos Publications

Library Without Walls Project

LANL Hot Topics: A new feature on the Library's Web Page.

Wurktorce Restructuring Plan

The Galvin Report

Tacical Gi)als for Los Alamos Nalional Laboraturv FY95 (PDF 496Kb)

Tautical Guals for Lus Alamus National Laboratorv FY GS (lexl versioni

Proposed LS Budget for FY" 96

Access to other electronic information is also available here. This includes:

Libary Information and Publications

Infumation Rescurces by Subjed

Electronic Texts

burnal Tables of Contents

Our Web page is under construction; click here to see a list of new items.

Access to more traditional materials is available through the Library's online catalog.

The Library is a member of the Library Services Alliance of New Mexico and provides electronic access to other New Mexico libraries, as well as the University of California (MELVYL) union catalog. For a map of the route to Los Alamos click here.

The knowledgeable staff at the Library can assist you in using these sources as well as providing more traditional library services.

Comments and suggestions may be directed to $l i b$-infe(a $l a m ! . g 01$.

Library Staff Only 
Appendix C.

Abstract from the 13th Annual Poster Session at the American Library Association Conference, Miami Beach, 1994

Strategies for Promoting a Consortium: Library Services Alliance of New Mexico. Jeanne G. Howard and Marilyn Von Seggern; New Mexico State University, Las Cruces; Washington State University, Pullman.

Founded in 1992, the Library Services Alliance of New Mexico is a consortium for scientific, technical, and engineering information owned by the libraries of three research laboratories and three universities located in New Mexico. During the strategic planning sessions the need to publicize the consortim to researchers and scientists, university and laboratory administrators, and state politicians was recognized. The following initiatives were launched:

- the signing of a Memorandum of Agreement by the Alliance members in Albuquerque in January 1992 with the news media present;

- $\quad$ presentations about the Alliance at state and special library association meetings, to the State Librarian in Santa Fe, and at the Department of Energy (DOE) library director's meeting in Los Alamos:

- the preparation of a brochure to be distributed throughout the state to researchers, scientists, organizations and institutions;

- lobbying the New Mexico State Legislature for funding for the 1994 library initiative, "Collections and Connections".

Expected results are increased awareness and visibility for Alliance libraries; support for library collections and services; cooperative collecting strategies and resource sharing; and shared access to the expert collective knowledge of the libraries' staff members. 